\section{Impact of a Brief Postharvest Hot Water Drench Treatment on Decay, Fruit Appearance, and Microbe Populations of California Lemons and Oranges}

\author{
Joseph L. Smilanick, ${ }^{1}$ \\ David Sorenson, ${ }^{2}$ \\ Monir Mansour, ${ }^{3}$ \\ Jonah Aieyabei, ${ }^{4}$ and \\ Pilar Plaza ${ }^{5}$
}

Additional INDEX wORDS. Geotrichum candidum, hot water treatment

Summary. A brief (15 or 30 seconds) high-volume, low-pressure, hot-water drench at $68,120,130,140$, or 145 ${ }^{\circ} \mathrm{F}(20.0,48.9,54.4,60.0$, or 62.8 $\left.{ }^{\circ} \mathrm{C}\right)$ was applied over rotating brushes to 'Eureka' lemons (Citrus limon) and 'Valencia' oranges (Citrus sinensis). The impact of this treatment on populations of surface microbes, injury to the fruit, the incidence of green mold (Penicillium digitatum)or sour rot (Geotrichum citri-aurantii), when inoculated into wounds one day prior to treatment, and temperatures required to kill the spores of these

We thank the California Citrus Research Board fo financial assistance, John Maze, Louis Whitendale, and Walter Stutzman of the Univeristy of California Lindcove Research and Extension Center for access to their facilities, help in the fabrication of equipment, and assistance in the design and execution of the tests, and we acknowlegde the advice of Larry Zettler and Dennis Margosan in assembly and review of the manuscript.

${ }^{1}$ Research plant pathologist, USDA-ARS, San Joaquin Valley Agricultural Sciences Center, 9611 S. Riverbend Ave., Parlier, CA 93648

${ }^{3}$ Visiting scientist and horticulturalist, USDA-ARS, San Joaquin Valley Agricultural Sciences Center, 9611 S. Riverbend Ave., Parlier, CA 93648.

${ }^{4}$ Biological aide, USDA-ARS, San Joaquin Valley Agricultural Sciences Center, 9611 S. Riverbend Ave. Parlier, CA 93648

${ }^{2}$ Technical specialist, Sunkist Growers, $222 \mathrm{~W}$ Lindmore Street, Lindsay, CA 93247.

${ }^{5}$ Visiting Scientist, Área de Postcollita, CeRTA, Centre UdL-IRTA, Lleida, Catalonia, Spain. fungi and $P$. italicum suspended in hot water were determined. Fruit microbial populations were determined immediately after treatment. Decay and injuries were assessed after storage for 3 weeks at $55{ }^{\circ} \mathrm{F}(12.8$ $\left.{ }^{\circ} \mathrm{C}\right)$. The efficacy of the hot water treatments was compared to immersion of fruit in 3\% wt/vol sodium carbonate at $95{ }^{\circ} \mathrm{F}\left(35.0{ }^{\circ} \mathrm{C}\right)$ for 30 seconds, a common commercial practice in California. Initial yeast and mold populations, initially $\log _{10} 6.0$ per fruit, were reduced to $\log _{10} 3.3$ on lemons and $\log _{10} 4.2$ on oranges by a 15-second treatment at $145^{\circ} \mathrm{F}$. Green mold control improved with increasing temperature and treatment duration. Green mold incidence was reduced from $\mathbf{9 7 . 9 \%}$ and $\mathbf{9 8 . 0 \%}$ on untreated lemons and oranges, respectively, to $14.5 \%$ and $9.4 \%$ by 30 seconds treatment with $145{ }^{\circ} \mathrm{F}$ water. However, immersion of lemons or oranges in 3\% wt/vol sodium carbonate was superior and reduced green mold to $8.0 \%$ and $8.9 \%$, respectively. Sour rot incidence on lemons averaged $84.3 \%$ after all water treatments, and was not significantly reduced, although arthrospores of G. citriaurantii died at lower water temperatures than spores of $P$. digitatum and $P$. italicum in in vitro tests. Sodium carbonate treatment for $\mathbf{3 0}$ seconds at $95{ }^{\circ} \mathrm{F}$ reduced sour rot to $36.7 \%$.

None of the treatments caused visible injuries to the fruit.

$\mathrm{G}$ reen mold of citrus, caused by Penicillium digitatum, blue mold of citrus, caused by Penicillium italicum, and sour rot, caused by Geotrichum citri-aurantii, are the most economically important postharvest diseases of citrus in arid growing regions of the world. The primary infection courts of these pathogens are wounds on fruit inflicted during harvest and subsequent handling, and these infections must be eradicated to achieve acceptable levels of control (Eckert and Brown, 1986; Powell, 1908). Currently, measures used to manage postharvest decay of citrus include treatments usually incorporated into fruit waxes, such as the fungicides sodium orthophenylphenate (SOPP), imazalil, and thiabendazole, or biological control formulations containing Candida oleophila (Aspire, Ecogen, Langhorne, Pa.) or Pseudomonas syringae (BioSave, EcoScience, Orlando, Fla.) (Brown and Chambers, 1996; Eckert and Eaks, 1989). Fruit are also immersed in tanks containing sodium bicarbonate at ambient temperatures (Smilanick et al., 1999), or heated solutions of SOPP, sodium carbonate, or a mixture of borax and boric acid (Eckert and Eaks, 1989). Several issues make the development of new treatments important, including concerns about human health risks associated with fungicide residues, particularly in the diets of children (National Research Council, 1993), the widespread occurrence of fungicide-resistant isolates of $P$. digitatum (Holmes and Eckert, 1999), environmental problems associated with the disposal of water used in packing operations, and a lack of approved fungicides for the control of sour rot (Eckert and Eaks, 1989). Hot water treatments to control postharvest diseases of citrus avoid residue and disposal issues associated with chemical treatments. Immersion of fruit into hot water for several minutes duration has been extensively investigated for the control of green mold (Houck, 1967; Smoot and Melvin, 1965), blue mold (Palou et al., 2001), and brown rot (Feld et al., 1979; Klotz and DeWolfe 1961a), caused by Phytopthora spp. Control of green mold requires higher temperatures and is less feasible than control of brown rot because of the risk of injury to the fruit (Eckert and Eaks, 1989). For example, Palou and coworkers (2001) evaluated control of blue mold and the rind appearance of oranges after hot water treatments of $2.5 \mathrm{~min}$ duration. Partial control blue mold began at temperatures of $122^{\circ} \mathrm{F}(50.0$ ${ }^{\circ} \mathrm{C}$ ) and improved as the temperature increased. Water temperatures of 127 ${ }^{\circ} \mathrm{F}\left(52.8{ }^{\circ} \mathrm{C}\right)$ caused some minor injury, while moderate or severe injuries occurred after treatment at $131{ }^{\circ} \mathrm{F}$ $\left(55.0^{\circ} \mathrm{C}\right)$ or $135{ }^{\circ} \mathrm{F}\left(57.2^{\circ} \mathrm{C}\right)$ and higher, respectively. Recently, Porat and coworkers (2000a, 2000b) evaluated a short hot water brushing treatment where citrus fruit (Citrus spp.) were treated for seconds. Green mold incidence was reduced by $45 \%$ to $55 \%$ on 'Minneola' tangerines (Citrus paradisi x C. reticulata), 'Shamouti' oranges (C. sinensis), and 'Star Ruby' red grapefruit (C. paradisi) by a $20 \mathrm{~s}$ treament of $133{ }^{\circ} \mathrm{F}\left(56.1{ }^{\circ} \mathrm{C}\right)$ water without injury to the fruit (Porat et al., 2000a). The resistance of 'Star Ruby' grapefruit to chilling injury was greatly enhanced (Porat et al., 2000b). 
Our objectives were to fabricate a high volume, low pressure hot water drench device and determine the impact of various water temperature and treatment time combinations on 1 ) the control of postharvest green mold on lemons and oranges, and sour rot on lemons; 2) the natural populations of yeasts and molds (U.S. Food and Drug Administration, 1995) and bacteria; and 3 ) the appearance of citrus fruit.

\section{Materials and methods}

Fruit. 'Eureka' lemons or 'Valencia' oranges that had been commercially harvested no more than $2 \mathrm{~d}$ before were randomized for use in these tests. The oranges were of typical commercial maturity and originated from a grove in the San Joaquin Valley of California. The lemons inoculated with $P$. digitatum were light-green in color, while those inoculated with $G$. citri-aurantii were yellow. The lemons originated from a coastal grove near Oxnard, Calif. The tests were done in May and June of 2000.

Pathogen culture and inoculaTION. In every experiment, the fruit were randomized, inoculated, and kept at $68{ }^{\circ} \mathrm{F} 24 \mathrm{~h}$ before treatment. P. digitatum isolate M6R (from J. W. Eckert, University of California, Riverside) and a P. italicum isolate that originated from an infected lemon, were cultured 1 to 2 weeks on potato dextrose agar (PDA). Spores were harvested by adding $5 \mathrm{~mL}$ of sterile, deionized water containing $0.05 \% \mathrm{t}$ octylphenoxypolyethoxyethanol (Triton X-100; Sigma Chemical Co., St Louis, Mo.) to the petri dish, rubbing the surface with a sterile glass rod, passing the suspension through two layers of cheese cloth. The suspension was diluted with water to an absorbance of 0.1 at $425 \mathrm{~nm}$ determined with a spectrophotometer; this density contains about $10^{6}$ spores $/ \mathrm{mL}(2.96 \times$ $10^{7}$ spores/fl oz) (Eckert and Brown, 1986). Penicillium italicum was used only in in vitro hot water spore mortality tests. Lemons and oranges were inoculated about $24 \mathrm{~h}$ before hot water treatment by dipping a steel rod with a 1 -mm-wide $\times 2$-mm-long tip into the solution of spores of $\mathrm{P}$. digitatum and making a single wound per fruit with the rod. Geotrichum citri-aurantii was similarly cultured and prepared and lemons were similarly inoculated, except the inoculum solution contained $10 \mu \mathrm{g} \cdot \mathrm{mL}^{-1}(\mathrm{ppm})$ cycloheximide to facilitate infection (Eckert and Brown, 1986) and 100 $\mu \mathrm{g} \cdot \mathrm{mL}^{-1}$ thiabendazole to minimize interference from $P$. digitatum. Four replications of 25 fruit each were prepared. After treatment, G. citriaurantii-inoculated fruit were placed in cavity trays to minimize the spread of sour rot among fruit that contacted each other. After hot water treatment, all fruit were left unwaxed and stored for 3 weeks at $55^{\circ} \mathrm{F}$, then the number of decayed fruit was counted.

Hot WATER EQUiPMENT. All treatments were applied at the Fruit Evaluation Center Packline of the Lindcove Research and Extension Center of the University of California, in Lindcove, Calif. An FMC pressure washer (Food Machinery Corporation, Lindsay, Calif.) was converted to deliver a high volume, low pressure hot water drench over rotating brushes. The pressure washer brushes (Tufted Polycor brushes; Industrial Brush Co., Pomona, Calif.) were $2 \mathrm{ft}(61.0 \mathrm{~cm})$ wide and 4.5 inches $(11.43 \mathrm{~cm})$ in diameter. The filaments of the brush were 0.15 inch $(38 \mathrm{~mm})$ in diameter with 20 tufts per circumference. The brushes rotated at $80 \mathrm{rpm}$. The opennings of the water delivery nozzles were 13 inches $(33.0 \mathrm{~cm})$ above top of brushes. A high volume of heated water was applied over the brushes through a single 5 -ft-long $(1.5-\mathrm{m})$ row of 16 solid-cone nozzles at 3.75 -inch $(9.53-\mathrm{cm})$ intervals, on a 1 -inch $(2.54$ $\mathrm{cm})$ inside diameter pipe down the center of the brush bed. Each nozzle delivered $0.55 \mathrm{gal} \cdot \mathrm{min}^{-1}\left(2.1 \mathrm{~L} \cdot \mathrm{min}^{-1}\right)$ at $5 \mathrm{lb} / \mathrm{inch}^{2}(34.5 \mathrm{kPa})$. The nozzles were supplied by a 550 -gal (2082-L) capacity heated water tank delivered through an insulated, 1 inch insidediameter hose. The water tank was heated by a natural gas boiler and could reach a maximum temperature of about $150{ }^{\circ} \mathrm{F}\left(65.6{ }^{\circ} \mathrm{C}\right)$. A 25 horsepower pump pressurized the nozzles at about $5 \mathrm{lb} /$ inch $^{2}$ and returned a volume of about $8.8 \mathrm{gal} / \mathrm{min}$ $\left(33.6 \mathrm{~L} \cdot \mathrm{min}^{-1}\right)$ of used water to the tank for reheating. The residence time of fruit under the hot water drench was $15 \mathrm{~s}$; this was controlled and prolonged to $30 \mathrm{~s}$ by turning on and off a pusher bar. The temperature of the treatments we report are of the drench water recorded at two locations 2 inches $(5.1 \mathrm{~cm})$ above the brush bed with type T thermocouples (model HHII; Omega Engineering, Stamford,
Conn.) with stainless steel probes, one near the front of the brush bed, the other in the center. The temperature of applied water was controlled by the average reading of these two thermocouples, and it was maintained within $2{ }^{\circ} \mathrm{F}\left(1.1^{\circ} \mathrm{C}\right)$ during treatment. The temperature of the fruit was monitored with a combination infrared and type $\mathrm{K}$ thermocouple thermometer (model OS643W; Omega Engineering). Sodium carbonate ( $3 \% \mathrm{wt} / \mathrm{vol}$, $\mathrm{pH} 11.5$ ) was applied by immersion of the fruit for $30 \mathrm{~s}$ into $4 \mathrm{gal}(15.1 \mathrm{~L})$ of the solution, followed by drying of the fruit in air. The solution temperature was $95 \pm 4{ }^{\circ} \mathrm{F}\left(35.0 \pm 2.2^{\circ} \mathrm{C}\right)$.

QUANTIFICATION OF MICROBE POPULATIONS. Three replicate samples of eight fruit each were removed just after treatment from the hot water drench and placed in zip lock bags, placed on ice, and the total yeast and mold and bacteria populations were determined using standard methods (U.S. Food and Drug Adminstration, 1995; Pao et al. 1998). To determine the populations of spores or natural microbes, each replicate was sealed inside 1.1-gal (4-L) sterile plastic bags containing $500 \mathrm{~mL}$ of $0.1 \%$ peptone and $0.01 \%$ Triton X-100 (each wt/ $\mathrm{vol}$ ), and placed a reciprocating shaker [displacement 4 inches $(10.2 \mathrm{~cm}), 100$ cycles/min]. After $20 \mathrm{~min}$, the samples were inverted and shaken for an additional $20 \mathrm{~min}$. Serial dilutions were prepared and $0.2 \mathrm{~mL}$ volumes of each were dispensed into duplicate 100$\mathrm{mm}$-diameter petri dishes containing dichloran rose-bengal chloramphenicol (DRBC)(Difco, Chicago) or plate count agar (PCA)(Difco). DRBC dishes were incubated at $68^{\circ} \mathrm{F}$ for $5 \mathrm{~d}$ then colonies of yeast and molds were enumerated. PCA was incubated at 99 ${ }^{\circ} \mathrm{F}\left(37.2^{\circ} \mathrm{C}\right)$ for $2 \mathrm{~d}$ then colonies of aerobic mesophilic bacteria (Food and Drug Adminstration of the United States, 1995) were enumerated. The experiment was repeated twice.

FruIT QUALITY. Noninoculated oranges and lemons free of surface blemishes were selected and treated to determine if injury was caused by any of the treatments. After treatment, the fruit were not waxed and stored for 3 weeks at $55^{\circ} \mathrm{F}$, then they were divided into the following categories based on their appearance: $0=$ perfect, $\mathrm{l}=$ slight surface blemishes present, $2=$ moderate surface blemishes present, $3=$ severe surface blemishes present. There 
Table 1. Analysis of variance of the incidence of green mold-infected lemons and oranges that developed during 3 weeks storage at $55^{\circ} \mathrm{F}\left(12.8^{\circ} \mathrm{C}\right)$. Before storage, the lemons and oranges were treated with a water drench for 15 or $30 \mathrm{~s}$ applied at a temperature of $68,120,130,140$, or $145{ }^{\circ} \mathrm{F}(20.0,48.9,54.4$, 60.0 , or $62.8^{\circ} \mathrm{C}$ ) over rotating brushes. A transformation (arcsin of the square root of the proportion of infected fruit) was applied to the incidence of green mold before analysis.

\begin{tabular}{lrrrrr}
\hline Source & df & $\begin{array}{r}\text { Sum of } \\
\text { squares }\end{array}$ & $\begin{array}{c}\text { Mean } \\
\text { square }\end{array}$ & \multicolumn{1}{c}{ F } & $P$ \\
\hline Water temperature $(\mathrm{WT})$ & 4 & 27792.2 & 6948.1 & 121.83 & 0.0001 \\
Treatment time $(\mathrm{TT})$ & 1 & 4272.1 & 4272.1 & 74.91 & 0.0001 \\
Fruit variety $(\mathrm{FV})$ & 1 & 458.0 & 458.0 & 8.03 & 0.0061 \\
FV $\times$ WT & 4 & 1192.7 & 298.2 & 5.23 & 0.0010 \\
FV $\times$ TT & 1 & 371.0 & 371.0 & 6.51 & 0.0131 \\
FV $\times$ TT $\times$ WT & 8 & 2187.6 & 273.4 & 4.79 & 0.0001 \\
Residual & 66 & 3764.1 & 57.0 & & \\
\end{tabular}

were three replicates of 10 fruit each. Fruit of the first two classes would classify as USDA No. 1, while those of 2 or 3 would be downgraded to choice or rejected, respectively.

Mortality OF SPORES IN WATER. A dense (about $1 \times 10^{5}$ spores $/ \mathrm{mL}$ ) suspension of spores was prepared in water as previously described from the same isolates. A glass test tube containing $9 \mathrm{~mL}$ of deionized water was suspended in a temperature-controlled water bath (model FK; Haake Corp., Saddle Brook, N.J.) until the test temperature was attained. The water temperature was continuously monitored with a thermocouple with 1-mm-diameter type $\mathrm{T}$ probe (model HHII; Omega Engineering). The thermocouple was calibrated with a precision mercury thermometer (Miller and Weber, Inc., New York). The precision mercury thermometer was calibrated at $32,77,95,113$, and $131^{\circ} \mathrm{F}$ $\left(0.0,25.0,35.0,45.0\right.$, and $\left.55.0^{\circ} \mathrm{C}\right)$ by the method of Wise (1991) and the error of readings at each calibration temperature was less than $0.036{ }^{\circ} \mathrm{F}$ $\left(0.02^{\circ} \mathrm{C}\right)$. The water temperatures used were a control of $75^{\circ} \mathrm{F}\left(23.8^{\circ} \mathrm{C}\right)$, and 113 to $140^{\circ} \mathrm{F}\left(60.0^{\circ} \mathrm{C}\right)$ in increments of $4.5^{\circ} \mathrm{F}\left(2.50^{\circ} \mathrm{C}\right)$. One $\mathrm{mL}$ of the spore suspension was added to the tube suspended in the water bath and after 15 or $30 \mathrm{~s}$ the tube was removed and plunged into an ice bath. Serial dilutions of the solution were prepared, and $0.2 \mathrm{~mL}$ of each were applied to three replicate DRBC agar plates. The plates were incubated $4 \mathrm{~d}$ at $68{ }^{\circ} \mathrm{F}$, then the colonies were counted. Each experiment was repeated three times.

Statistical analysis. An analysis of variance was applied to the square root of the arcsin of the proportion of infected fruit, followed by Fisher's protected least significant difference (LSD) test $(P=0.05)$ to separate means. Paired $t$ tests were applied in some tests. Actual values are shown. The mortality of spores in water was analysed by probit analysis (SPSS version 10; SPSS Inc., Chicago) to estimate temperatures that killed $50 \%$ and 95\% $\left(\mathrm{LT}_{50}\right.$ and $\mathrm{LT}_{99}$, respectively) of the spores in 15 and $30 \mathrm{~s}$. The $\mathrm{LT}_{50}$ and $\mathrm{LT}_{99}$ values from three experiments with each fungus were compared by an analysis of variance followed by Fisher's protected LSD test $(P=0.05)$.

\section{Results}

The incidence of green mold decreased significantly as the water temperature increased, when the duration of treatment increased from 15 to $30 \mathrm{~s}$, and it was similarly effective on lemons and oranges (Table 1, Fig. 1). Interactions among water temperatures, treatment time, and fruit variety were significant(Table 1). The magnitude of the control of green mold was high; its incidence was reduced from $97.9 \%$ and $98.0 \%$ on untreated lemons and oranges, respectively, to $14.5 \%$ and $9.4 \%$ by 30 s treatment with $145^{\circ} \mathrm{F}$ water (Fig. 1). However, green mold incidence after immersion of lemons or oranges in $3 \% \mathrm{wt} /$ vol sodium carbonate was $8.0 \%$ lower than after the most severe water treatment, although these differences were not statistically significant. Sour rot incidence on lemons averaged $84.3 \%$ after all water treatand $8.9 \%$, respectively, and ments, and was not significantly reduced by any of them. Conversely, immersion in sodium carbonate for 30 s reduced sour rot to $36.7 \%$ (Fig. 2). Yeast and mold populations, initially $\log _{10} 6.0$ per fruit, were reduced to $\log _{10}$ 3.3 on lemons and $\log _{10} 4.2$ on oranges by $15 \mathrm{~s}$ treatment at $145^{\circ} \mathrm{F}$ (Fig. 3 ). Water-treated oranges had more surface blemishes after treatment than untreated fruit, but none had visible injuries associated with increases in the duration of treatment or water temperature (Fig. 4). Lemons were not visibly changed by any treatment.

Water temperatures that killed spores of $P$. italicum and P. digitatum were similar and higher than those that killed arthrospores of G. citri-aurantii (Fig. 5). The $\mathrm{LT}_{50}$ and $\mathrm{LT}_{95}$ temperatures of spores of $P$. digitatum in $15 \mathrm{~s}$ were about $9.4^{\circ} \mathrm{F}\left(5.22{ }^{\circ} \mathrm{C}\right)$ higher than that of arthrospores of G. citriaurantii, and those of spores of $P$. digitatum in $30 \mathrm{~s}$ were about $6.2^{\circ} \mathrm{F}$

Fig. 1. Percentage ( \pm SD) of greenmold infected lemons and oranges that developed during 3 weeks storage at $55{ }^{\circ} \mathrm{F}\left(12.8^{\circ} \mathrm{C}\right)$. Before storage, the lemons and oranges were not treated (control) or treated with a water drench for 15 or $30 \mathrm{~s}$ applied at a temperature of $68,120,130,140$, or $145{ }^{\circ} \mathrm{F}(20.0,48.9,54.4,60.0$, or $62.8{ }^{\circ} \mathrm{C}$ ) over rotating brushes, or they were immersed in sodium carbonate $\left(\mathrm{Na}_{2} \mathrm{CO}_{3}\right)(3 \%$ wt/vol, $\mathrm{pH}$ 11.5) solution temperature at $100 \pm 4$ ${ }^{\circ} \mathrm{F}\left(37.8 \pm 2.2{ }^{\circ} \mathrm{C}\right)$ for $30 \mathrm{~s}$.

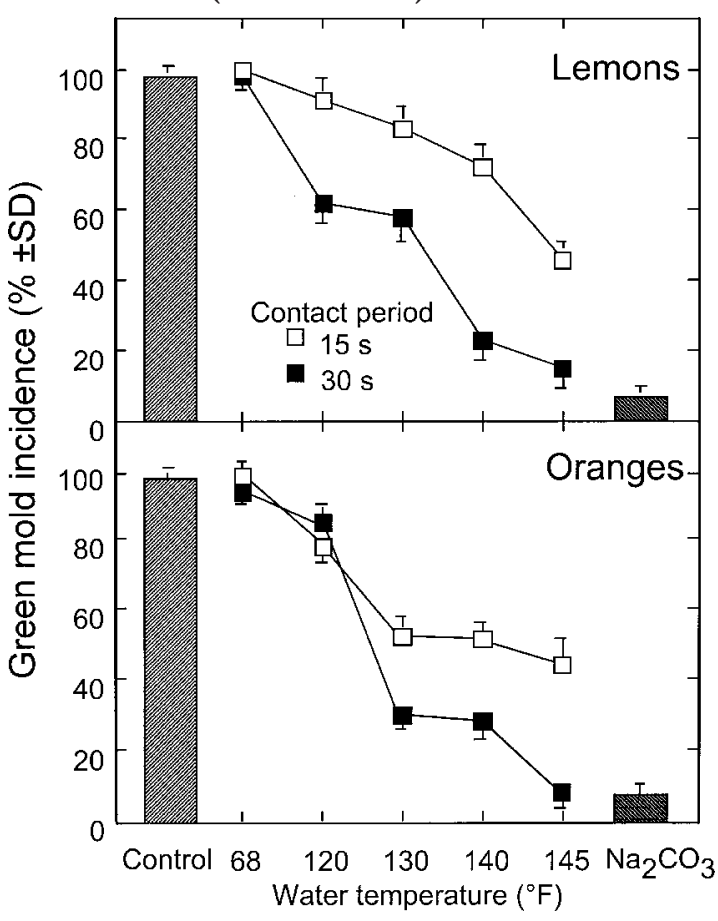




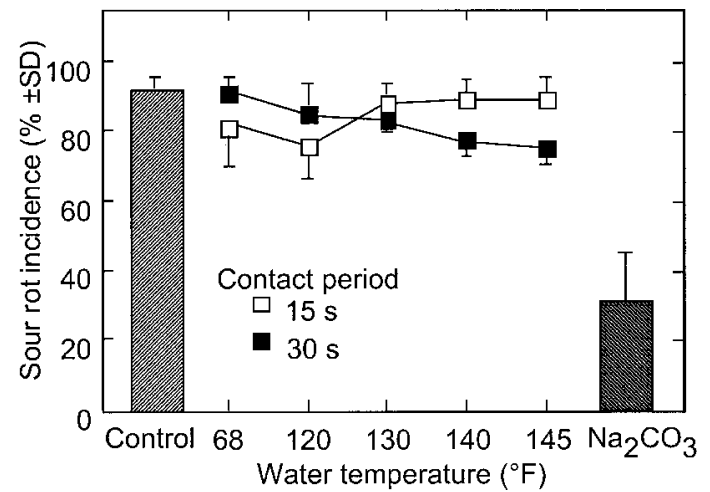

Fig. 2. Percentage ( $\pm S D$ ) of sour-rot infected lemons that developed during 3 weeks storage at $55{ }^{\circ} \mathrm{F}(12.8$ $\left.{ }^{\circ} \mathrm{C}\right)$. Before storage, the lemons were not treated (control) or treated with a water drench for 15 or $30 \mathrm{~s}$ applied at a temperature of $68,120,130,140$, or $145^{\circ} \mathrm{F}(20.0,48.9,54.4,60.0$, or $62.8^{\circ} \mathrm{C}$ ) over rotating brushes, or they were immersed in sodium carbonate $\left(\mathrm{Na}_{2} \mathrm{CO}_{3}\right)((3 \%$ wt/vol, $\mathrm{pH}$ 11.5) solution temperature at $100 \pm 4$ ${ }^{\circ} \mathrm{F}\left(37.8 \pm 2.2{ }^{\circ} \mathrm{C}\right)$ for $30 \mathrm{~s}$.

$\left(3.44^{\circ} \mathrm{C}\right)$ higher (Table 2). The $\mathrm{LT}_{50}$ and $\mathrm{LT}_{95}$ temperatures of spores of $P$. italicum and $P$. digitatum were not significantly different (Table 2).

\section{Discussion}

A brief hot water brushing treatment significantly reduced green mold on lemons and oranges and reduced surface microflora without harming the appearance of the fruit. However, a temperature regime capable of controlling green mold did not control sour rot, and this disease is an important problem for the California industry. Why sour rot was not controlled is

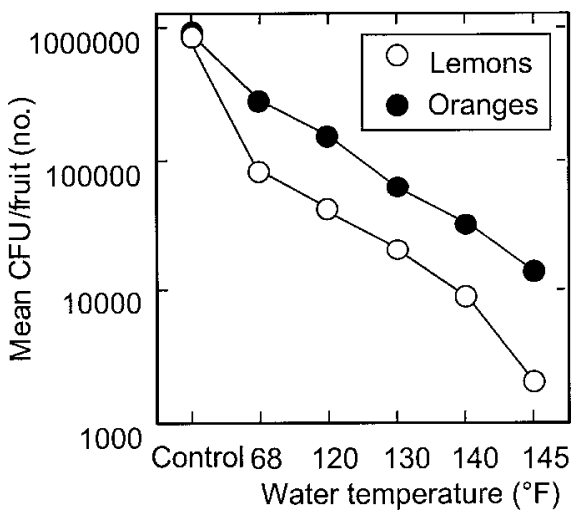

Fig. 3. Colony-forming units (CFU) of natural yeasts and molds on lemons and oranges not treated (control) or after treatment with a water drench for 15 or $30 \mathrm{~s}$ applied at a temperature of $68,120,130,140$, or $145{ }^{\circ} \mathrm{F}(20.0,48.9,54.4,60.0$, or $62.8{ }^{\circ} \mathrm{C}$ ) over rotating brushes. unknown, particularly since arthrospores of G. citri-aurantii died in water at much lower temperatures than those of $P$. digitatum. Lesions characteristic of sour rot developed deeply in the fruit and presumably were protected from heat, while those of green mold typically were limited to the albedo. However, at the time of treatment, little lesion development had occurred with either pathogen. There is recent evidence that the mode of action of hot water treatment is not thermal mortality of the pathogens alone. Nafussi and coworkers (2001) showed treatment of lemons for 2 min with water at 127 ${ }^{\circ} \mathrm{F}$ caused a transient inhibition in the growth of $\mathrm{P}$. digitatum for 24 to $48 \mathrm{~h}$, during which lignin production, scoparone, and scoletin accumulated in inoculated wounds and infections were delayed or stopped. Short hot water treatments induced $\mathrm{Bl}-3$ glucanases and chitinases in grapefruit that were correlated with increased resistance to infection (Pavoncello et al., 2001). Perhaps these defensive reactions induced by thermal treatments that inhibit $P$. digitatum infections fail to inhibit those of G. citri-aurantii.

Our results corroborate many aspects of the work of Porat and coworkers (2000a), who reported a hot water brush treatment at $133{ }^{\circ} \mathrm{F}$ for $20 \mathrm{~s}$ reduced green mold incidence and fruit surface microflora substantially without harm to the fruit. They showed that the treatment caused a redistribution of epiculticular waxes to cover and seal stomata and cracks on the fruit surface. Juice acidity, soluble solids content, and the rate offruit weight loss during storage were unchanged. Control of sour rot was not assessed in their work, nor did they compare the hot water treatment to immersion of the fruit in sodium carbonate, a practice used in California and accepted as a certified organic treatment (Smilanicketal., 1997, 1999). Sodium carbonate partially but significantly reduced sour rot incidence in this and prior tests (Smilanick and Sorenson, 2001), and there are no fungicides registered for use in the United
States that control this disease.

Benefits of a hot water brush treatment include the following.

1) Substantial control of green mold, and presumably all $P$. digitatum isolates would be controlled, even those with high levels of fungicide resistance. These are common in California packinghouses (Holmes and Eckert, 1999) and this treatment could be incorporated in strategies to manage fungicide-resistant isolates.

2) Other diseases likely to be controlled include blue mold and particularly brown rot, caused by Phytopthora spp., because brown rot is controlled at lower temperatures than green mold (Klotz and DeWolfe, 1961a; Smoot and Melvin, 1965).

3 ) The fruit are cleaned effectively by the treatment, and other cleaning operations, such as washing with high water-pressure or rotary brushes, could be reduced or eliminated.

4) The disposal of soiled water from a hot water brush treatment is easier than the disposal of other solutions used to control green mold, such as SOPP, sodium carbonate, sodium bicarbonate, or borax-boric acid.

5 ) The need to purchase, store, mix, and dispose of fungicides is eliminated. 6) Because fungicide use is avoided, the treatment would not disqualify the fruit as organic for marketing purposes.

7) Because the treatment caused large reductions in epiphytic microbe populations, a hot water brush treatment could be an element in compliance

Fig. 4. Percentage of lemons or oranges with visible surface defects that developed during 3 weeks storage at $55{ }^{\circ} \mathrm{F}\left(12.8^{\circ} \mathrm{C}\right)$. Before storage, the lemons and oranges were not treated (control) or treated with a water drench for 15 or 30 s applied at a temperature of $68,120,130,140$, or $145{ }^{\circ} \mathrm{F}(20.0,48.9,54.4,60.0$, or $62.8^{\circ} \mathrm{C}$ ) over rotating brushes.

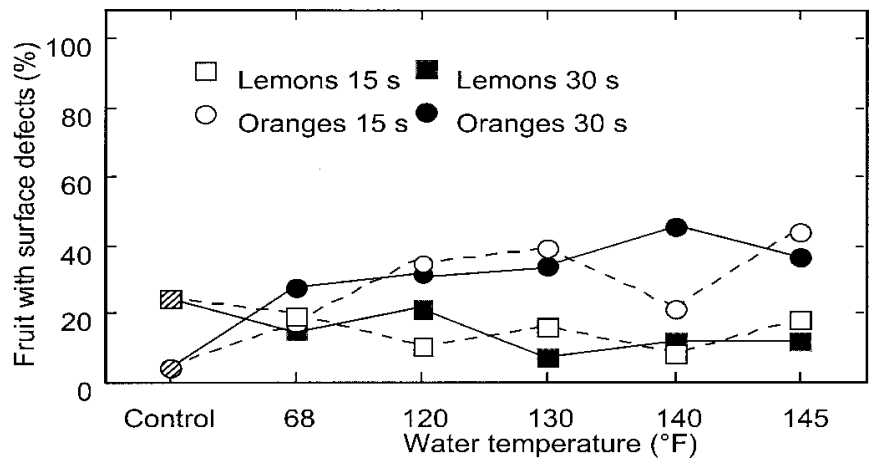




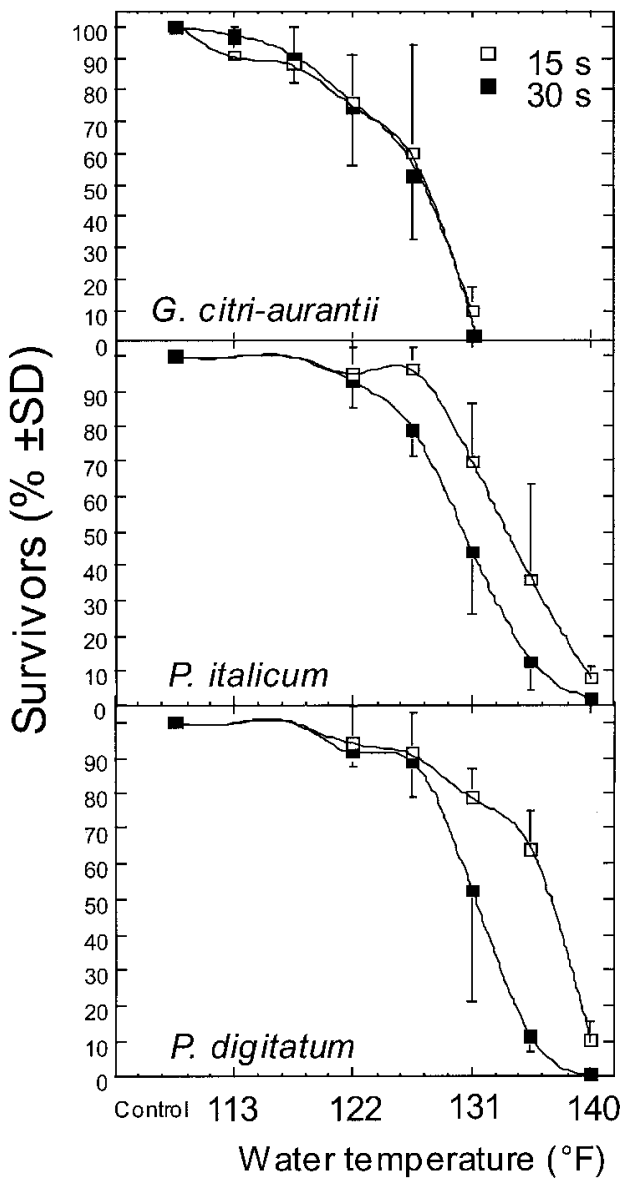

Fig. 5. Mortality of arthrospores of Geotrichum citvi-aurantii and spores of Penicillium digitatum and $\boldsymbol{P}$. italicum after immersion in hot water for 15 or $30 \mathrm{~s}$. Values are the mean of three experiments; ${ }^{\circ} \mathrm{C}=5 / 9\left({ }^{\circ} \mathrm{F}-32\right)$.

with risk minimization programs such as hazard analysis, critical control point (HACCP) or good agricultural practices (GAP) guidelines to minimize the occurence of human pathogens on fresh produce (Harris etal., 2002). Sanitiation by hot water is particularly valuable for processors who must avoid high levels of chlorine in order to comply with organic certification rules.

8) The quality of the finish of fruit waxes may improve because the deposition, coverage, and rate of drying of fruit waxes applied to warm fruit is generally superior than that applied to cooler fruit.

9) Brief hot water treatment reduces the susceptibility of citrus fruit to subsequent chilling injury. This has been shown repeatedly after hot water dip treatments of 1 to 4 min duration on many citrus fruit varieties (McLauchlan et al., 1997; Rodov et al., 1995; Wild and Hood, 1989) and after a 30-s 140 ${ }^{\circ} \mathrm{F}$ hot water brush treatment on 'Star
Ruby' grapefruit, where chilling injury was reduced by $70 \%$ to $90 \%$ after storage for 6 weeks at $36^{\circ} \mathrm{F}$ $\left(2.2^{\circ} \mathrm{C}\right)$ (Porat et al., 2000b).

10) The water is sufficently heated in the hot water brush applications that propagules of pathogens and other microbes washed off into it will not survive, so disinfectants to santitize the solution, such as chlorine, are not needed.

Risks of a hot water brush treatment include the following.

1) The thresholds of hot water injury to the fruit are incompletely known and influenced by season of harvest, grove location, and variety. 2) Green mold is not completely controlled, and sour rot, an important disease in California, is not controlled.

3) Additional equipment, energy costs, and packinghouse space are needed to install and operate the equipment.

4) Fruit warming caused by the treatment could increase subsequent cooling needs. We found the initial surface temperature of $70{ }^{\circ} \mathrm{F}(21.1$ $\left.{ }^{\circ} \mathrm{C}\right)$ increased to $84^{\circ} \mathrm{F}\left(28.9^{\circ} \mathrm{C}\right)$ when measured one minute after a $15 \mathrm{~s}$ treatment at $140^{\circ} \mathrm{F}$, and to $88^{\circ} \mathrm{F}$ $\left(31.1^{\circ} \mathrm{C}\right)$ when measured one minute after a $30 \mathrm{~s}$ treatment at this temperature. At the fruit center, treatment for $30 \mathrm{~s}$ at $140{ }^{\circ} \mathrm{F}$ raised the temperature about $10 \mathrm{~min}$ following treatment to a maximum of $5.5^{\circ} \mathrm{F}\left(3.06^{\circ} \mathrm{C}\right)$ above the original temperature of $68^{\circ} \mathrm{F}$.

5 ) There is no antifungal residual on treated fruit to protect them from subsequent inoculation, although this treatment did induce some resistance in 'Star Ruby' grapefruit to green mold when inoculations were made after treatment (Pavoncello et al., 2001). 6) The treatment adds additional mechanical brushing during processing of the fruit, so the occurrence of superficial brush injuries to the fruit, particularly seen on oranges and grapefruit when brushing is prolonged (Davis et al., 1963; Eaks, 1959; Eckert and Eaks, 1989), may increase.

The risk of hot water injury has been the primary barrier to the commercial implemetation of hot water treatment of fresh citrus fruit and this issue deserves special attention and evaluation by those who want to employ this process. Many workers immersed citrus fruit in water at high temperatures without injury to the fruit (Barkai-Golan etal., 1969; Houck, 1967; Schirra and Mulas, 1993; Smoot and Melvin, 1965) and prior reports showed hot water brush treatments as high as $145^{\circ} \mathrm{F}$ were tolerated without injury (Porat et al., 2000a, 2000b). Citrus fruit can vary widely in their tolerance to heat, even within the same variety (Fawcett, 1936; Harding and Savage, 1964; Houck, 1967). To control green mold, Houck (1967) recommended 5 to $10 \mathrm{~min}$ immersion of lemons in water at $125^{\circ} \mathrm{F}\left(51.7^{\circ} \mathrm{C}\right)$ or 1 min at $130{ }^{\circ} \mathrm{F}$. This treatment was just tolerated by yellow, winter-harvested lemons, the most sensitive fruit he tested, and was readily tolerated by green, summer-harvested lemons, which were very resistant to heat injury and could tolerate much higher temperatures. Klotz and DeWolfe (196la, 1961b) cautioned that although lemons could routinely tolerate immersion in water for $4 \mathrm{~min}$ or longer at $115^{\circ} \mathrm{F}$ $\left(46.1^{\circ} \mathrm{C}\right.$ ) to $120^{\circ} \mathrm{F}$ without injury, release of rind oils leading to oleocellosis could occur if lemons were cold and turgid at the time of immersion. They and others (Fawcett, 1936; Houck, 1967) recommended fruit conditioning, which consists of a delaying immersion for 1 to $4 \mathrm{~d}$ after harvest to allow the rind to lose turgor. Conditioning other

Table 2. Water temperatures that killed $50 \%$ and $99 \%\left(\mathrm{LD}_{50}\right.$ and $\left.\mathrm{LD}_{99}\right)$ of the spores of Penicillium digitatum or P. italicum or the arthrospores of Geotrichum citri-aurantii in 15 or $30 \mathrm{~s} . \mathrm{LD}_{50}$ and $\mathrm{LD}_{99}$ values were determined by probit analysis and are the means of three experiments.

\begin{tabular}{lccccc}
\hline & \multicolumn{4}{c}{ Water temperature ${ }^{\circ} \mathrm{F}^{\mathrm{z}}$} \\
\cline { 2 - 4 } \cline { 2 - 3 } Fungus & $\mathbf{L D}_{50}$ & $\mathbf{L D}_{99}$ & & $\mathbf{L D}_{50}$ & $\mathbf{L D}_{99}$ \\
\hline P. digitatum & $135.0 \mathrm{a}^{\mathrm{y}}$ & $147.0 \mathrm{a}$ & & $130.5 \mathrm{a}$ & $139.6 \mathrm{a}$ \\
P. italicum & $133.2 \mathrm{a}$ & $142.3 \mathrm{ab}$ & & $130.6 \mathrm{a}$ & $140.2 \mathrm{a}$ \\
G. citri-aurantii & $125.4 \mathrm{~b}$ & $137.8 \mathrm{~b}$ & & $124.5 \mathrm{~b}$ & $133.3 \mathrm{~b}$ \\
\hline
\end{tabular}

${ }^{\circ} \mathrm{C}=5 / 9\left({ }^{\circ} \mathrm{F}-32\right)$.

yalues followed by unlike letters within columns are significantly different by Fisher's least significant difference $(P$ $=0.05$ ). 
fruits or vegetables for periods of hours or days in warm air improves their tolerance to hot water treatments (Lurie, 1998). Without conditioning, turgid, freshly picked, winter-harvested lemons could be injured by temperatures as low as $100{ }^{\circ} \mathrm{F}\left(37.8^{\circ} \mathrm{C}\right)$ (Fawcett, 1936). Conditioning improves the heat tolerance of lemons, while delays of this duration in the processing of oranges and grapefruit are less feasible because they can cause significant increases in rind breakdown and susceptibility to brushing injury, even when noheat treatmentisemployed(Davis et al., 1963). Other aspects of the hot water brushing process remain to be evaluated. We used a common cylindrical packingline brush in our device, but the best brush to employ for this process has not been determined. The brushes must tolerate the hot water for long periods, maximize cleaning, and minimize injury to the fruit.

Although sour rot was not controlled by the hot water brush regimes we tested, the technique could conceivably affect some reduction in this disease by other means. Hot water would kill waterborne inoculum minimize spread of arthrospores among the fruit during processing. As cited previously, hot water treatments substantially reduce chilling injury. Hotwater treated lemons may be able to tolerate prolonged storage at $41^{\circ} \mathrm{F}(5.0$ $\left.{ }^{\circ} \mathrm{C}\right)$, a temperature $9^{\circ} \mathrm{F}\left(5.0^{\circ} \mathrm{C}\right)$ cooler than that commonly used today, and low enough to stop sour rot development (Eckert and Eaks, 1989). Furthermore, because the infectivity of G. citriaurantiiinoculum is increased substantially when coinfection with $P$. digitatum occurs (Morris, 1982), elimination of the later by hot water might reduce the incidence of sour rot.

\section{Literature cited}

Barkai-Golan, R., R.S. Kahan, and R. Padova. 1969. Synergistic effects of gamma radiation and heat on the development of Penicillium digitatum in vitro and in stored citrus fruits. Phytopathology 59:922-924.

Brown, G.E. and M. Chambers. 1996. Evaluation of biological products for the control of postharvest diseases of Florida citrus. Proc. Fla. State Hort. Soc. 109:278-282.

Davis, P.L., P.L. Harding, and M.B. Sunday. 1963. Factors affecting rind breakdown of citrus fruits. USDA Agr. Mktg. Serv. Res. Rpt. 596.

Eaks, I.L. 1959. Brush effects on oranges. Calif. Citrograph 44:141-143.
Eckert, J.W. and G.E. Brown. 1986. Evaluation of postharvest treatments for citrus fruits, p. 92-97. In: K.D. Hickey (ed.). Methods for evaluating pesticides for control of plant pathogens. Amer. Phytopathol. Soc., St. Paul, Minn.

Eckert, J.W. and I.L. Eaks. 1989. Postharvest disorders and diseases of citrus fruits, p. 179-260. In: W. Reuther, E.C. Calavan, and G.E. Carman, (eds.). The citrus industry. vol. 4. Univ. Calif. Press, Berkeley.

Fawcett, H.S. 1936. Citrus diseases and their control. 2nd ed. McGraw Hill, N.Y.

Feld, S.J., J.A. Menge, and J.E. Pehrson. 1979. Brown rot of citrus: A review of the disease. Citrograph 64:101-106.

Harding, P.R. and D.C. Savage. 1964. Investigation of possible correlation of hotwater washing with excessive storage decay in coastal California lemon packing houses. Plant Dis. Rptr. 48:808-810.

Harris, L.J., D. Zagory, and J.R. Gorny. 2002. Safety factors, p. 301-314. In: A. A. Kader (ed.). Postharvest technology of horticultural crops. 3rd ed. Univ. Calif. Agr. Nat. Res. Publ. 3311.

Holmes, G.J. and J.W. Eckert. 1999. Sensitivity of Penicillium digitatum and $P$. italicum to postharvest citrus fungicides in California. Phytopathology 89:716-721.

Houck, L.G. 1967. Hot water treatments for control of penicillium green mold of Eureka lemons. Phytopathology 57:99. (Abstr.)

Klotz, L.J. and T.A. DeWolfe. 1961a. Limitations of the hot water immersion treatment for the control of phytophthora brown rot oflemons. Plant Dis. Rptr. 45:264-267.

Klotz, L.J. and T.A. DeWolfe. 1961b. Brown rot contact infection of citrus fruits prior to hot water treatment. Plant Dis. Rptr. 45:268-271.

Lurie, S. 1998. Postharvest heat treatments. Postharvest Biol. Technol. 14:257-269.

McLauchlan, R.L., S.J. Underhill, J.M. Dahler, and J.E. Giles. 1997. Hot water dipping and low temperature storage of 'Eureka' lemons. Austral. J. Expt. Agr. 37:249-252.

Morris, S.C. 1982. Synergism of Geotrichum candidum and Penicillium digitatum in infected citrus fruit. Phytopathology 72:13361339.

Nafussi, B., S. Ben-Yehoshua, V. Rodov, J. Peretz, B.K. Ozer, and G.D. Hallewin. 2001. Mode of action of hot-water dip in reducing decay of lemon fruit. J. Agr. Food Chem. 49:107-113.

National Research Council. 1993. Pesticides in the diets of infants and children. Natl. Acad. Press, Wash., D.C.

Palou, L., J.L. Smilanick, J. Usall, and I. Vinas. 2001. Control of postharvest blue and green molds of oranges by hot water, sodium carbonate, and sodium bicarbonate. Plant Dis. 83:371-376.
Pao, S., G.E. Brown, and C. Davis. 1998. Reduction of microorganisms on citrus fruit surfaces during packinghouse processing. J. Food Prot. 61:903-906.

Pavoncello, D., S. Lurie, S. Droby, and R. Porat. 2001. A hot water treatment induces resistance to Penicillium digitatum and promotes accumulation of heat shock and pathogenesis-related proteins in grapefruit flavedo. Physiol. Plant. 111:17-22.

Porat, R., A. Daus, B. Weiss, L. Cohen, E. Fallik, and S. Droby. 2000a. Reduction of postharvest decay in organic citrus fruit by a short hot water brushing treatment. Postharvest Biol. Technol. 18:151-157.

Porat, R., D. Pavoncello, J. Peretz, S. BenYehoshua, S. Lurie. 2000b. Effects of various heat treatments on the induction of cold tolerance and on the postharvest qualities of 'Star Ruby' grapefruit. Postharvest Biol. Technol. 18:159-165.

Powell, G.H. 1908. The decay of oranges while in transit from California. USDA Bur. Plant Ind. Bul. 123.

Rodov, V., S. Ben-Yehoshua, R. Albarli, and D.O. Fang. 1995. Reducing chilling injury and decay of stored citrus fruit by hot water dips. Postharvest Biol. Technol. 5:119-127.

Schirra, M. and M. Mulas. 1993. Keeping quality of 'Oroblanco' grapefruit-type as affected by hot dip treatments. Adv. Hort. Sci. 7:73-76.

Smilanick, J.L., B.E. Mackey, R. Reese, J. Usall, and D.A. Margosan. 1997. Influence of the concentration of soda ash, temperature, and immersion period on the control of postharvest green mold of oranges. Plant Dis. 81:379-382.

Smilanick, J.L., D.A. Margosan, F. Mlikota, J. Usall, and I.F. Michael. 1999. Control of citrus green mold by carbonate and bicarbonate salts and the influence of commercial postharvest practices on their efficacy. Plant Dis. 83:139-145.

Smilanick, J.L. and D. Sorenson. 2001. Control of postharvest decay of citrus fruit with calcium polysulfide. Postharvest Biol. Technol. 21:157-168.

Smoot, J.J. and C.F. Melvin. 1965. Reduction of citrus decay by hot-water treatment. Plant Dis. Rptr. 49:463-467.

U.S. Food and Drug Administration. 1995. Bacteriological analytical manual. 8th ed. Amer. Assn. Off. Anal. Chem. Intl., Gaithersburg, Md.

Wild, B.L. and C.W. Hood. 1989. Hot dip treatments reduce chilling injury in longterm storage of 'Valencia' oranges. HortScience 24:109-110.

Wise, J.A. 1991. A procedure for the effective recalibration of liquid-in-glass thermometers. Publ. SP-819. Natl. Inst. Stnd. Technol., Gaithersburg, Md. 